\title{
ХАРАКТЕРИСТИКА ПРОДУКТІВ ОЗОНУВАННЯ ІМІТАТОРІВ РАДІОАКТИВНО-ЗАБРУДНЕНИХ ТРАПНИХ ВОД АЕС
}

\author{
Б.Г. Шабалін ${ }^{1}$ О.М. Лавриненко ${ }^{1,2}$, К.К. Ярошенко ${ }^{1}$, В.В. Вембер ${ }^{3}$ С.П. Бугера ${ }^{1}$

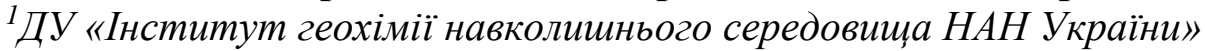 \\ пр. Палладіна, 34a, Київ, 03142, Україна \\ ${ }_{2}^{2}$ Інститут проблем матеріалознавства ім. I. М. Франщевича НАН Украйни \\ вул. Кржижановського, 3, Київ, 03680, Україна \\ ${ }^{3}$ Національний технічний університет України \\ "Київський політехнічний інститут ім. Ігоря Сікорського" \\ пр. Перемоги, 37, Київ, 03056, Україна \\ e-mail: b_shabalin@ukr.net; alena.lavrynenko@gmail.com
}

Однією з невирішених екологічних проблем сьогодення на АЕС України є відсутність завершеного технологічного циклу переробки рідких радіоактивних відходів (РРВ) до отримання кінцевого продукту, придатного для подальшого довготривалого зберігання $\mathrm{i}$ захоронення. В процесі експлуатації АЕС утворюються значні обсяги радіоактивнозабруднених трапних вод (ТРВ), переробка яких складається із операцій приймання i попередньої обробки; очистки на випарних установках та вузлах доочищення дистиляту; видачі кубового залишку і соляного плаву, що підлягають тривалому зберіганню [1]. До голових джерел формування трапних вод належать технологічні операції періодичної промивки внутрішніх поверхонь обладнання та трубопроводів першого і другого контурів AEC; обробка спецпралень і душових дезактиваційними розчинами [2]. Використання дезактиваційних розчинів, до складу яких входять етилендіамінтетраоцтова (ЕДТА) та щавлева кислоти, перешкоджає роботі випарних установок внаслідок утворення нерозчинних сполук у змійовиках. В свою чергу, наявність в складі розчинів органічних сполук знижує вірогідність контакту катіонів металів і радіонуклідів з поверхнею аніонітів і катіонітів, i, таким чином, унеможливлює ефективне проходження адсорбційних процесів. В цілому, видалення або руйнування металоорганічних комплексів радіонуклідів кобальту, мангану та інших продуктів корозії металічних частин обладнання, які знаходяться в зоні високої щільності потоків нейтронів і $\gamma$-опромінення, $\epsilon$ однією 3 найскладніших задач при знешкодженні РРВ. Припускається, що попереднє руйнування комплексів органічних сполук з радіонуклідами або їх видалення може суттєво спростити подальше поводження із РРВ.

Аналіз вітчизняних і закордонних джерел інформації $[3,4]$ свідчить про те, що при виборі технологічних схем переробки РРВ атомних електростанцій перевага надається осадовосорбційній технології, на перших стадіях якої передбачається руйнування органічних комплексних сполук трапних вод окиснювальними методами, що дасть змогу виключити їх негативний вплив на подальші процеси сорбційного очищення PРB i сконцентрувати радіонукліди РРВ у невеликому об'ємі кінцевого радіоактивного продукту з подальшим кондиціонуванням вторинних відходів методами цементації, оскловування, керамізації тощо. 
Одним з найефективніших і відносно простих окиснювальних методів руйнування аніонів оксалату, ЕДТА та інших органічних сполук у водних розчинах вважається озонування, при впровадженні якого в якості окиснювача складових розчинів використовують озон [5]

Тому метою роботи стало вивчення фазового та хімічного складу продуктів озонування модельних розчинів - імітаторів трапних вод АЕС з реакторами ВВЕР.

Склад РРВ усіх АЕС України практично не відрізняється один від одного i, за вмістом макрокомпонентів, представлений солями натрію і миючими засобами аніонної природи. Зазвичай для вітчизняних АEC, оснащених реакторами ВBEP, сумарний солевміст різних компонентів в суміші трапних вод у середньому складає 3-5 і може досягати 15 г/дм³ [6].

Радіоактивні речовини трапних вод знаходяться у формі гідратованих і комплексних іонів, нейтральних молекул і колоїдних частинок. Основними радіонуклідами є продукти поділу урану в урановому паливі $-{ }^{137} \mathrm{Cs} \mathrm{i}{ }^{90} \mathrm{Sr}$ та продукти активації - ${ }^{60} \mathrm{Co},{ }^{54} \mathrm{Mn}$. Характеризуючись відносно невеликим періодом напіврозпаду, ${ }^{60} \mathrm{Co}\left(\mathrm{T}_{1 / 2}=5,27\right.$ років), сумарно із ізотопом ${ }^{137} \mathrm{Cs}$ $\left(\mathrm{T}_{1 / 2}=30,17\right.$ років), визначають радіаційний фон як експлуатаційних $\mathrm{PPB}$, так і відходів, які залишаються при демонтажі енергоблоків АЕС, що виводяться з експлуатації після остаточної зупинки або тривалої консервації [4]. На практиці за час роботи реактору активність ${ }^{60} \mathrm{Co}$ становить близько $90 \%$ загальної активності корозійних відкладень. Для ізотопів ${ }^{137} \mathrm{Cs} \mathrm{i}{ }^{90} \mathrm{Sr}$ характерна іонна форма знаходження в трапних водах. Радіонуклиди ${ }^{60} \mathrm{Co}$ i ${ }^{54} \mathrm{Mn}$ утворюють комплекси з ЕДТА і щавлевою кислотою.

Для проведення експериментального дослідження склад модельного розчину трапних вод було розраховано згідно даних усередненого складу РРВ чотирьох АЕС України з реакторами типу ВВЕР (Таблиця 1).

Таблиця 1.

Склад вихідного модельного розчину трапних вод [7].

\begin{tabular}{|c|c|c|c|c|c|}
\hline $\begin{array}{c}\text { Макро- } \\
\text { компоненти }\end{array}$ & $\begin{array}{c}\text { "Концентрація, } \\
\text { мг/дм }{ }^{3}\end{array}$ & $\begin{array}{c}\text { Мікро- } \\
\text { компоненти }\end{array}$ & $\begin{array}{c}\text { Концентрація, } \\
\text { мг/дм }\end{array}$ & Радіонукліди & $\begin{array}{c}\text { Активність, } \\
\text { Бк/дм }{ }^{3}\end{array}$ \\
\hline $\mathrm{BO}_{3}{ }^{3-}$ & 1500 & $\mathrm{Co}^{2+}$ & 36,5 & ${ }^{40} \mathrm{~K}$ & 550 \\
\hline $\mathrm{Na}^{+}$ & 4600 & $\mathrm{Mn}^{2+}$ & 8,5 & ${ }^{90} \mathrm{Sr}$ & 32000 \\
\hline $\mathrm{K}^{+}$ & 1000 & $\mathrm{Sr}^{2+}$ & 45 & ${ }^{137} \mathrm{Cs}$ & 34500 \\
\hline $\mathrm{Cl}^{-}$ & 3500 & $\mathrm{Cs}^{+}$ & 36 & \multirow{5}{*}{\multicolumn{2}{|c|}{$\begin{array}{l}\mathrm{pH}_{\text {розчину }}=11,5 \\
\text { Солевміст }=17,6 \text { г/дм }\end{array}$}} \\
\hline $\mathrm{NO}^{3-}$ & 1600 & $\mathrm{Ca}^{2+}$ & 0,8 & & \\
\hline $\mathrm{SO}_{4}{ }^{2-}$ & 4000 & $\mathrm{Fe}^{3+}$ & 0,7 & & \\
\hline$P$ & 120 & ЕДТА & 100 & & \\
\hline СПАР\# & 350 & $\mathrm{C}_{2} \mathrm{O}_{4}^{2-}$ & 40 & & \\
\hline
\end{tabular}

* - дані, отримані розрахунковим методом, \# - синтетичні поверхнево-активні речовини

Одним із головних чинників, який впливає на ступінь сорбції ${ }^{60} \mathrm{Co}$ i ${ }^{54} \mathrm{Mn} 3$ розчинів на ферумовмісних осадах під час озонування, $є$ водневий показник (значення $\mathrm{pH}$ ) середовища. Зокрема, при значенні $\mathrm{pH}>12$ коефіцієнт розподілу ${ }^{60} \mathrm{Co}{ }^{54} \mathrm{Mn}$ між твердою і рідкою фазами знижується. Крім того, за означених умов збільшується розчинність гідроксидів і оксигідроксидів феруму, тобто починається руйнування сорбентів, які використовують для зв'язування радіонуклідів. Водночас, при значенні $\mathrm{pH}<11$ спостерігається різке зниження розчинності боратів, наявних у розчині. Таким чином, з урахуванням перелічених чинників для досягнення максимального ефекту озонування водневий показник розчину мав бути 
скоригованим до значення 11,5 . Температура озонування складала $60{ }^{\circ} \mathrm{C}$. Ступінь руйнування органічних комплексів визначали біхроматним методом хімічного споживання кисню (ХСК), яке значною мірою визначає ступінь видалення радіонуклідів ${ }^{60} \mathrm{Co}$ i ${ }^{54} \mathrm{Mn}$ iз розчину. В ході процесу озонування спостерігалось зниження показника ХСК від 960 до 18 мгО 2/дм³. Вміст розчиненого кисеню при озонуванні складав 52-57 \%; відносний відсоток радіоактивного

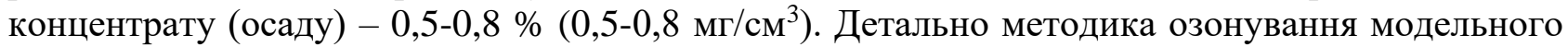
розчину викладена в [7].

Визначення фазового складу отриманих зразків проводили методом рентгенофазового аналізу (РФА) на пристрої ДРОН-3,0 з випромінюванням мідного аноду $\left(\mathrm{CuK}_{\alpha}\right)$. Шаг сканування становив $0,05-0,1^{0}$, експозиція - 4 с, діапазон кутів $2 \Theta$ - від 15 до $90^{\circ}$. Зйомку зразків проводили за стандартної температури. Ідентифікацію мінерального складу проводили відповідно до картотеки ASTM Powder diffraction file 2003. PDF-2, Database, Sef.1-89. Дослідження морфології зразків і їх елементного складу проводили методом скануючої електронної мікроскопії (СЕМ) і електронно-дисперсійної спектроскопії (ЕДС) на растровому електронному мікроскопі Tescan Mira 3 LMU, обладнаному енергодисперсійним модулем для мікроаналізу.

В процесі озонування модельного розчину - імітатора трапної води, проходить руйнування органічних комплексів та утворення твердої фази, в складі якої фіксуються ${ }^{60} \mathrm{Co},{ }^{54} \mathrm{Mn} \mathrm{i}{ }^{55} \mathrm{Fe}$. 3a даними РФА, складові осаду характеризуються нанометровими розмірами частинок та значним вмістом аморфної складової (Рис. 1). Головними ферумовмісними фазами визначено оксигідроксиди феруму - лепідокрокіт $ү$-FeOOH (JCPDS \# № 08-0098) і гетит $\alpha-\mathrm{FeOOH}$ (JCPDS \# № 17-536). Вміст фази із структурою феришпінелі, вірогідно, магеміту $\gamma-\mathrm{Fe}_{2} \mathrm{O}_{3}$ (JCPDS \# № 4-0755), незначний. В складі зразків припускається наявність низки кристалогідратів основних солей змішаного складу, але їх ідентифікація ускладнена слабким рівнем кристалічності зразків та перекриттям відбиття від характеристичних міжплощинних відстаней (дифракційних піків) кількох мінеральних фаз. Входження до складу осаду феришпінелі, зокрема магеміту, надає йому феромагнітних властивостей, що може стати важливим чинником для його подальшої утилізації.

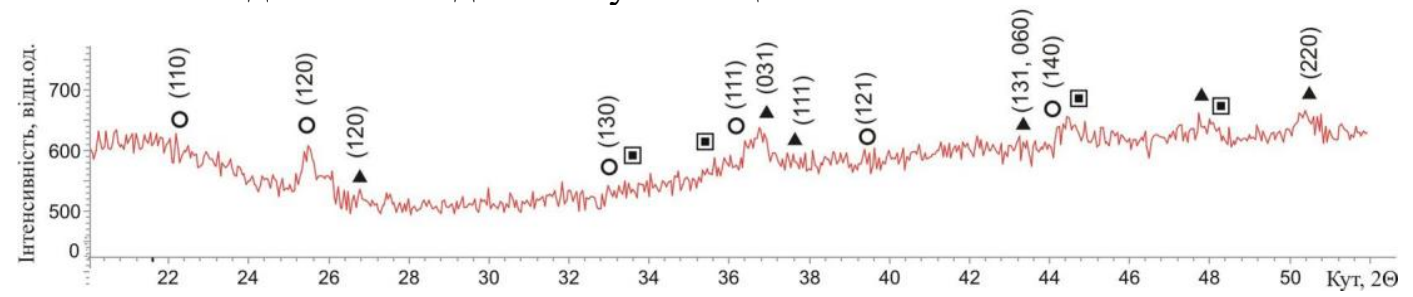

Рисунок 1. Дифрактограма осаду, отриманого при озонуванні модельного розчину імітатора трапних вод. Умовні позначки: $\bigcirc \quad$ - гетит; $\stackrel{\mathcal{\Lambda}}{-}$-лепідокрокіт; $\square$ - Fe(II)Fe(III) шаруваті подвійні гідроксиди (Green Rust).

На СЕМ зображенні осаду (Рис. 2а) наявні тонкодисперсні частинки сферичної форми, вірогідно, оксиди металів, розмірами 20-30 нм, асоційовані у щільні мікророзмірні агрегати та їх асоціати різної конфігурації, зазвичай із чіткими контурами, розміром від 100 до 250 нм. Структури у формі платівок належать шаруватим подвійним гідроксидам (ШПГ) змішаного складу, зокрема $\mathrm{Fe}-\mathrm{Co}$ [8] та оксигідроксидам феруму - гетиту і лепідокрокіту. Вірогідним механізмом фазоутворення є сумісне осадження розчинених органічних компонентів та поліконденсація осаду, що супроводжується адсорбційними процесами. 
Після проведення озонування у складі осаду наявні $\mathrm{Mn}, \mathrm{Fe}, \mathrm{Co}$ i, незначні концентрації $\mathrm{Sr}$. Варіації елементного складу осаду залежно від морфології складових зразка виявились несуттєвими. За відсотковим вмістом компонентів (ваговим та атомним) простежується ряд: $\mathrm{Mn}>\mathrm{Fe}>\mathrm{Co}>\mathrm{Sr}>\mathrm{Na}>\mathrm{Mg}$ (Рис. 2б, Таблиця 2), що узгоджується $з$ константами стійкості хелатних комплексів ЕДТА [9]. Наявність на спектрі благородних металів пов'язана із процедурою підготовки зразка - напиленням його поверхні Au i Pd.. Осади, які утворюються під час лужного озонування, найефективніше фіксують іони мангану, а найменш ефективно іони кобальту. Величина адсорбції радіонуклідів ${ }^{137} \mathrm{Cs}$ i ${ }^{90} \mathrm{Sr}$ на осадах незначна, тому під час озонуванні цезий і стронцій на 70-80 \% залишаються в розчині. Вірогідно, низька ефективність видалення кобальту пов'язана із його знаходженням в розчині у формі міцних органічних комплексів з ЕДТА та іонами оксалату. Припускається конкуруюча дія іонів мангану і феруму по відношенню до цезію і стронцію.

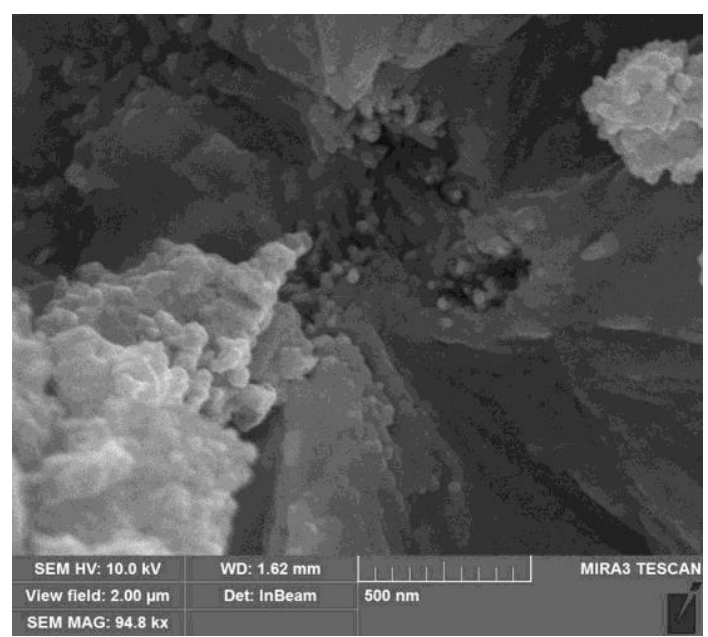

a

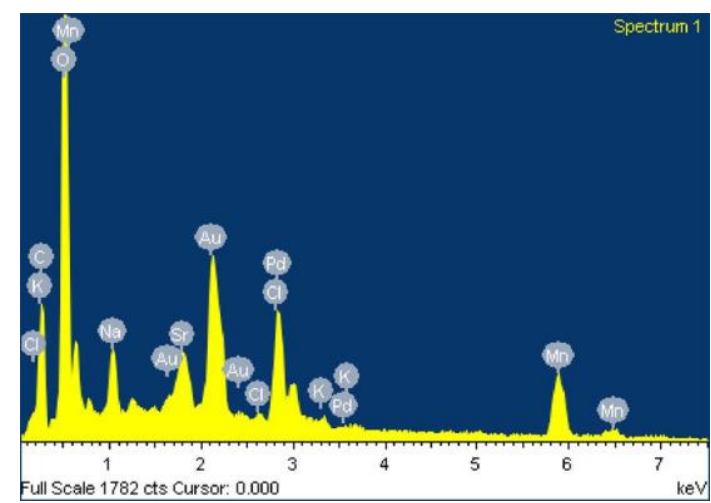

6

Рисунок 2. Електронно-мікроскопічне дослідження осаду, отриманого при озонуванні модельного розчину - імітатора трапних вод а - СЕМ зображення; б - ЕДС спектр.

Таблиця 2.

Елементний склад осадів, отриманих після озонування модельних розчинів трапних вод (за даними ЕДС).

\begin{tabular}{|c|c|c|c|c|c|c|c|c|c|c|c|}
\hline $\mathrm{C}$ & $\mathrm{O}$ & $\mathrm{Na}$ & $\mathrm{Mg}$ & $\mathrm{Si}$ & $\mathrm{K}$ & $\mathrm{Ca}$ & $\mathrm{Mn}$ & $\mathrm{Fe}$ & $\mathrm{Co}$ & $\mathrm{Sr}$ & Сума \\
\hline \multicolumn{8}{|c|}{ Вагові \% } \\
\hline 7,05 & 6,73 & 0,98 & 0,55 & - & - & - & 44,01 & 20,05 & 17,79 & 2,84 & 100,00 \\
\hline \multicolumn{8}{|c|}{ Aтомні \% } \\
\hline 22,87 & 16,38 & 1,66 & 0,88 & - & - & - & 31,20 & 13,98 & 11,76 & 1,26 & \\
\hline
\end{tabular}

Дослідження умов окиснення озоном модельних розчинів трапних вод $\mathrm{AEC}(\mathrm{pH}=11,5)$, які містять органічні компоненти (щавлеву кислоту та ЕДТА), довело [7], що під час озонування проходять процеси сумісного осадження та адсорбції металів на поверхню ферумовмісних сполук, що супроводжується окисненням органічних компонентів та зменшенням концентрації іонів марганцю на 94,3 \%, а кобальту - на $6 \%$; зниженням активності ${ }^{137} \mathrm{Cs}$ на 26 $\%,{ }^{90} \mathrm{Sr}$ - на $15,7 \%$. 
Осад, що утворюється під час озонування, складається із фаз лепідокрокіту і гетиту 3 домішкою феришпінелі, вірогідно, магеміту. Він характеризується нанометровими розмірами частинок і містить значний відсоток аморфної фази. До складу осаду входять катіони $\mathrm{Mn}, \mathrm{Fe}$, $\mathrm{Co}$ i, незначні концентрації $\mathrm{Sr}, \mathrm{Na}$ i Mg. За відсотковим вмістом компонентів (ваг.\% та ат. \%) простежується ряд: $\mathrm{Mn}>\mathrm{Fe}>\mathrm{Co}>\mathrm{Sr}>\mathrm{Na}>\mathrm{Mg}$, що узгоджується з константами стійкості хелатних комплексів ЕДТА. Під час озонування концентрація $\mathrm{Mn}^{2+}$ зменшується на 94,3\%, $\mathrm{Co}^{2+}$ - на $6 \%$, активність ${ }^{137} \mathrm{Cs}$ знижується на $26 \%$, а ${ }^{90} \mathrm{Sr}$ - на $15,7 \%$.

\section{Лiтература:}

1. О. Г. Батюхнова, К. Бергман, В. М. Ефременков, и др., Технологические и организационные аспекты обращения с радиоактивными отходами: серия учебных курсов Вена, МАГАТЭ, 2005, 230 с.

2. А. А. Ключников, Э. М. Пазухин, Ю. М. Шигера, Радиоактивные отходы АЭС и методы обращения с ними, К.: Институт проблем безопасности АЭС НАН Украины, 2005. - 487 с.

3. А. Е. Савкин, Разработка и испытания технологии переработки жидких радиоактивных отходов АЭС, Радиохимия, ha2011, Т. 53, № 5, С.470-473.,

4. О. Б. Андронов, О создании современной системы обращения с жидкими радиоактивными отходами на АЭС Украины. Постановка задачи, Проблеми безпеки атомних електростанцій $і$ Чорнобиля, 2015, Вип. 24, С. 32-41.

5. О. М. Лавриненко, Б. Г. Шабалін, Деструкція органічних речовин радіоактивнозабруднених вод атомних станцій, оснащених реакторами ВВЕР (аналітичний огляд), Ядерна енергетика та довкілля, 2020, № 3 (18), С.66-89.

6. А. С. Никифоров, В. В. Куличенко, М. И. Жихарев, Обезвреживание жидких радиоактивных отходов, Москва, Энергоатомиздат, 1985, 184 с.

7. К. К. Ярошенко, Б. Г. Шабалін, Г. М. Бондаренко, Дослідження процесів озонолізу органічних компонентів модельних розчинів рідких радіоактивних відходів реакторів ВВЕР, Ядерна енергетика та довкілля, 2020, № 4 (19), С. 32-39.

8. Е. Н. Лавриненко, Железосодержащие слоистые двойные гидроксиды как основа для получения дисперсных ферришпинелей, Nano Studies, 2016, № 13, pp. 93-116.

9. О. Гиленс, О.Н. Айкайме, Осаждение ЭДТА из комплексних растворов тяжелых металлов и его регенерирование, Технология и конструирование в электронной аппаратуре, 2004, № 4, С. 54-56. 